\title{
Anne Bradstreet's War Upon Tyranny
}

\author{
Megan Kluz a , Vincent King ${ }^{a}$
}

\begin{abstract}
In matters of religion, Puritans in the Massachusetts Bay Colony had to tread carefully. If they strayed from orthodox beliefs, they ran the risk of reproach and even excommunication. This was especially true of women. Ann Hutchinson is a prime example. She was initially highly popular for her home meetings, but she began to draw notice from the powerful men in the colony. Hutchinson was preaching that people could speak to God directly, essentially disempowering the church and the clergy. To one Puritan leader, John Winthrop, this kind of message was a direct threat to their power; therefore, Winthrop made it his mission to bring Hutchinson to trial and banish her from the colony. She was not the only unfortunate female that fell victim to the stone-like oppression of the Patriarchy. Anne Bradstreet's sister, Sarah Keayne, suffered a similar fate. She spoke out publicly against the injustices the Patriarchy committed against women. However, she failed to keep her social image intact. Winthrop and the other leaders stepped in to assert their authority against Keayne. As a result, Sarah Keayne was rejected by her husband and excommunicated from the church. Due to the fate of both women, the Puritan community was fearful that they, too, would become the next victims of the Patriarchy. Ann Hutchinson's and Sarah Keayne's social demise weighed heavily on Bradstreet's mind. Given that Anne Bradstreet's father and husband served on the court of magistrates that convicted Hutchinson, Bradstreet would have been all too aware of the dangers of criticizing the Patriarchy. Even though she was aware of these dangers, she did it anyway. But Bradstreet needed to be careful to remain well liked by her community, by both men and women. One social misstep would lead to her own excommunication, and women would be left with no one to fight for their basic rights. As Wendy Martin notes in An American Tritych, Bradstreet was a protofeminist who sought to change the power disparity between men and women to break the bonds of oppression for all women. This is particularly evident in the poems Martin does not examine. In "To Her Father with Some Verses," Bradstreet acknowledges that women are indebted to the Patriarchy but turns this debt to her advantage by making the Patriarchy acknowledge her value as a female writer.
\end{abstract}

Keywords: Anne Bradstreet; Feminism

In matters of religion, Puritans in the Massachusetts Bay Colony had to tread carefully. If they strayed from orthodox beliefs, they ran the risk of reproach and even excommunication. This was especially true of women. Ann Hutchinson is a prime example. She was initially highly popular for her home meetings, but she began to draw notice from the powerful men in the colony. Hutchinson was preaching that people could speak to God directly, essentially disempowering the church and the clergy. To one Puritan leader, John Winthrop, this kind of message was a direct threat to their power; therefore, Winthrop made it his mission to bring Hutchinson to trial and banish her from the colony. She was not the only unfortunate female that fell victim to the stone-like oppression of the Patriarchy. Anne Bradstreet's sister, Sarah Keayne, suffered a similar fate. She spoke out publicly against the injustices the Patriarchy committed against women. However, she failed to keep her social image intact. Winthrop and the other leaders stepped in to assert their authority against Keayne. As a result, Sarah Keayne was rejected by her husband and excommunicated from the church. Due to the fate of both women, the Puritan community was fearful that they, too, would become the next victims of the Patriarchy.

Ann Hutchinson's and Sarah Keayne's social demise weighed heavily on Bradstreet's mind. Given that Anne Bradstreet's father and husband served on the court of magistrates that convicted Hutchinson, Bradstreet would have been all too aware of the dangers of criticizing the Patriarchy. Even though she was aware of these dangers, she did it anyway. But Bradstreet needed to be careful to remain well liked by her community, by both men and women. One social misstep would lead to her own excommunication, and women would be left with no one to fight for their basic rights. As Wendy Martin notes in An American Tritych, Bradstreet was a protofeminist who sought to change the power disparity between men and women to break the bonds of oppression for all women. This is particularly evident in the poems Martin does not examine. In "To Her Father with Some Verses," Bradstreet acknowledges that women are indebted to the Patriarchy but turns this debt to her advantage by making the Patriarchy acknowledge her value as a female writer.

Bradstreet's first move to pursue gender equality is described in "To Her Father with Some Verses" where she portrays herself as the helpless debtor to her father. At the very beginning, Bradstreet primes her listeners to be sympathetic to her cause as she takes on the mask of humility. Martin praises Bradstreet on her use of humility when she states, "By presenting herself as insecure, insignificant, and inept, she hoped to disarm her potential opponents" (40). To disarm the Patriarchy, she uses language. In the poem, Bradstreet describes how her father's power influences her worth as a woman. He has the right to collect that same worth back from Bradstreet since he was the investor. Bradstreet writes, "Who can of right better demand the same / Than may your worthy self from whom it came?" (3-4). Her father, and by extension the Patriarchy, demand payment from the female populace for their services. We can assert that same and worth are equal quantities because Bradstreet owes a debt, a debt she will be required to pay at some point in her life. Her father is expecting to be paid in full for his investment in Bradstreet. But Bradstreet takes her debtor status and flips the power structure. She makes the case that she does "not know how to pay" her debt to her father (7). Given that Bradstreet's father was one of the Puritan leaders, he would be aware that he must act in accordance with Patriarchal expectations. Her father must demand payment from Bradstreet if he is to keep his power in the colony. But if Bradstreet cannot pay her father back in a 
traditional manner, then her father must forfeit his investment or accept another form of currency.

Bradstreet quickly makes her next move as she strategically turns the tables on the Patriarchy when she reminds them that women have nothing to give as payment. She blatantly states that men would lose their right to collect from her. Bradstreet writes, "Where nothing's to be had, kings lose their right" (10). Essentially, if a debtor is unable to pay their debt and has nothing left to use as payment, then the debt holder loses their right to collect from that person. Bradstreet is strongly suggesting to the male leaders that it is in their best interest to considers other forms of currency. Thus, this is where she gets to the heart of corruption within the Patriarchal system. Their power would be questioned if they did not collect from their subjects; therefore, she usurps the Patriarchy's power by becoming a debtor. Furthermore, her allusion to the Monarchy is a critique of the Patriarchy because they fled to America to escape the corruption of the King Charles I. Martin discusses how the Puritan leaders were "enraged by the abridgement of religious and civil rights and illegal taxes levied by Charles I, a group of beleaguered Puritans, including Anne Bradstreet's father and new husband, formed the New England Company with intention of emigrating" (23). Bradstreet is drawing similarities between the Patriarchy and the Monarchy to prove that this system of government is just as stifling as the government they fled. In an effort to liberate their congregation, the Puritans risked their lives to start a new life in a new country. She is trying to make her position in society relatable to the Puritan's experience in Europe. Bradstreet illustrates that her own suffering and the suffering of the women in the community is relatable to the injustices the Puritan men faced in Europe. Bradstreet's hopes that the Patriarchy will sympathize with her cause.

However, Bradstreet is not convinced that the Patriarchy's sympathy will be enough to change the male and female power structure; therefore, Bradstreet devises a solution. She will make incremental payments to the Patriarchy in the form of her poetry. She knows that they will not accept her writing willingly, so she minimizes its value. Yet again, Bradstreet utilizes humility to push her agenda. She plays on the Patriarchy greed for power by making them an offer. She writes, "Yet for my payment take this simple mite" (9). Bradstreet uses language that makes her poetry diminutive, so the Patriarchy does not feel like they are giving power to her. Instead the male leaders will feel vindicated when they can collect from her. Something is better than nothing in the eyes of the Patriarchy, even if that means blinding themselves to women stepping outside the domestic sphere. Bradstreet entices the Patriarchy further by advocating that her currency can become even greater. If men accept her small offering of poetry as currency, then Bradstreet can start writing more poetry that will make her even more valuable. She writes, "The principal might yield a greater sum, / Yet handled ill, amounts but to this crumb" (5-6). Bradstreet is saying that her initial investment from her father can become greater if it is cultivated. Bradstreet juxtaposes the larger sum against the crumb to establish that her father's investment in her has not been used idly. She is suggesting that we interpret her value as coming from the small amount to becoming a far greater amount if the Patriarchy accepts her poetry as currency. However, if the Patriarchy does not value her poetry, then her ability to pay will be diminished. Then, the Patriarchy would be left losing their right to collect from Bradstreet, and that is exactly what they want to avoid. This is an offer the Patriarchy cannot refuse because Bradstreet will continue to grow as a writer and produce many works over a life time.

Now that Bradstreet has manipulated the Patriarchy into accepting her poetry as currency, she makes her next move to keep the Patriarchy collecting from her. Bradstreet does not want the Patriarchy to forgive her debt because that means they will have to continue to value her writing. She discusses how her debt is a current and future obligation. She writes, "My bond remains in force unto this day" (8). Bradstreet is saying that she is accepting her existing debtor status, but she uses ambiguous language. She uses word play to perpetuate her debtor status, so day could mean any day at any time. By elongating or giving an inestimable time frame for the pay-off of her debt, Bradstreet is making her debtor status lifelong. She continues to persuade the Patriarchy to keep her debtor status active. Bradstreet says, "Such is my debt I may not say forgive, / But as I can, I'll pay it while I live" (11-12). Bradstreet is saying that she will not accept her debt as forgiven because she will pay it until the day she dies. Most people would think this would be fearsome, but to Bradstreet, this is the way to bring about social change in her community. Men will not let go of their power over women. While they think they are keeping their power by exacting payment and perpetuating male dominance, they are actually transferring power to women by allowing them to pursue individual desires. Then, if women are given the power to pursue individual desires, that will lead to women holding authority within their community. Bradstreet is working up to attaining this authority.

Although Bradstreet establishes that the Patriarchy is the institution that holds her bond, she makes her final move, asserting she is the authority of her debt. She establishes some control over her fate by taking responsibility as a debtor, and she plays on the greed of the Patriarchy to guarantee they will continue to take payment from her. Bradstreet says, "Such is my bond, none can discharge but I" (13). That is a bold statement for a woman in a Puritan community to say. She is taking the power away from the Patriarchy and bestowing it to herself knowing they will only wince a bit at her power-play. Essentially, they keep her in debtor status, but they lose their power to dictate when her debt is forgiven. Bradstreet will continue to pay the male leaders with her poetry, which will inspire other women to use other means of currency to pay their debts. Bradstreet ends her poem saying that she will not give up her value or her battle with the Patriarchy until she ceases to exist. Bradstreet writes, "Yet paying is not paid until I die" (14). The finality of this last line elicits conviction that Bradstreet has won her cause. Even though the Puritan society is still male dominated, Bradstreet has effectively won this skirmish. She is willing to be a debtor up until death to maintain her power in an oppressive world. She will not allow her debt to be forgiven until that time because it gives her autonomy outside of her domestic responsibilities. She is trying to educate the men and women within her community about the importance of equality. Bradstreet reclaimed a traditional form of oppression to assert her power against the Patriarchy.

Ultimately, Bradstreet's literary work sets the stage for future feminist revolutionaries. As a protofeminist, Bradstreet is fighting for the basic rights of women. She wants the male leaders to respect women and see them as people rather than objects of the domestic sphere. She demands that men view 
women as complex individuals who have human desires for autonomy and respect. Bradstreet demonstrates that women have a voice, a voice that must be heard in her community. She establishes a strategy to attack the Patriarchy in a way that keeps her out of their social crosshairs, strategies that future generations of feminists mimic to make headway against female oppression. Without Bradstreet and many other progressive female writers, the fight for women's rights would have been delayed longer than it already has been. Although we have not reached perfect equality between the sexes, Bradstreet's poetry opens the gates to social reformation.

\section{References}

Bradstreet, Ann. "To Her Father with Some Verses." Norton Anthology American Literature Beginnings to 1820, edited by Robert S. Levine, W.W. Norton \& Company, 2017, pp. 226.

Bradstreet, Ann. "To the Memory of My Dear and Ever Honored Father Thomas Dudley Esq. Who Deceased, July 31, 1653, and of His Age 77." Norton Anthology American Literature Beginnings to 1820 , edited by Robert S. Levine, W.W. Norton \& Company, 2017, pp. 224-226.

Martin, Wendy. An American Triptych: Ann Bradstreet, Emily Dickenson, Adrienne Rich. The University of North Carolina Press, 1984. 